\title{
Clinical and Etiological Characteristics of Epilepsy in the Elderly
}

\author{
Otto J. Hernandez Fustes ${ }^{1,2}$ Otto Hernandez-Cossio ${ }^{1,2}$ \\ ${ }^{1}$ InNeuro, Curitiba PR, Brasil \\ ${ }^{2}$ Department of Neurology, Hospital das Nações, Curitiba PR, Brasil
}

Address for correspondence Otto J. Hernandez Fustes, MD, Av. Marechal Floriano 170, Sala 1509, 80090-020, Curitiba/PR, Brasil, (e-mail: otto.fustes@hc.ufpr.br).

Our study shows that between 25 and 40 years the predominant etiological factors in epilepsy late are head injuries and brain tumors, while the most frequent cause of epilepsy above the 40 years old is cerebrovascular disease. ${ }^{5}$

It is necessary to exhaust the different study methods to rule out the possible causes of secondary epilepsy that allow an adequate etiological coping, as well as knowledge of the prognosis for each case; this fact takes on greater importance in the adult, in whom the disorder can generate functional and social restrictions.

\section{Conflict of Interest}

None declared.

\section{References}

1 Assadeck H, Toudou-Daouda M, Mamadou Z, MoussaKonate M, Hassane-Djibo F, Douma-Maiga D. Clinical and etiological characteristics of epilepsy in the elderly: a hospital-based study from a tertiary care referral center of Niamey, Niger. J Neurosci Rural Pract 2019;10(4):571-575

2 Hernández-Fustes OJ, López-Vizcarra H, Enríquez-Cáceres M, Hernández-Cossio O. Consideraciones acerca de las epilepsias tardías. Rev Neurol 2002;34(8):788-793

3 Hernández-Cossio O, Hernández-Oramas N, Enríquez-Cáceres M, Hernández-Fustes OJ. Epilepsias de comienzo tardío: estudio clínico. Rev Neurol 2001;32(11):1098-1099

4 Hernández-Fustes OJ, Hernández-Cossio O, Munhoz RP, et al. Epilepsia de inicio tardío no tumoral: estudio en pacientes hospitalizados mayores de 30 años de edad. Rev Neurol 2001; 33(4):394-395

5 Hernández-Cossio 0, Hernández-Oramas N, Enríquez-Cáceres M, Hernández-Fustes OJ. Etiología de las epilepsias de comienzo tardío. Rev Neurol 2001;32(7):628-630
DOI https://doi.org/

10.1055/s-0040-1713573

ISSN 0976-3147.
C2020 Association for Helping Neurosurgical Sick People

\section{License terms}

$(\circledast) \Theta \circledast$ 